\title{
Empirical Study of the Interactive Relationship between Producer Services and Manufacturing in Guangxi
}

\author{
Xin Zhu \\ Department of Management, \\ Guangxi University of Science and Technology, \\ Liuzhou, P.R.China \\ 5266736@qq.com
}

\author{
Kun Zhu \\ Department of Management, \\ Guangxi University of Science and Technology, \\ Liuzhou, P.R.China \\ 915270064@qq.com
}

\begin{abstract}
Based on Guangxi 1996-2012 time-series data, this paper uses gray relation analysis to analyze the relationship of producer services and manufacturing, through the establishment of the VAR model, impulse response function and variance decomposition method is used to test in producer services and manufacturing technical analysis in Guangxi. The results show that there is a long-term interaction between producer services and manufacturing, but the interactive development degree is low, there is a certain partiality, namely, producer services have a certain degree of support for manufacturing, but manufacturing pull function on the producer services are not obvious.
\end{abstract}

Keywords-producer services; manufacturing; interactive relationship; gray relational analysis; VAR model

\section{INTRODUCTION}

Producer services are directed production enterprises and other organizations to provide intermediate production activities in service industries. Interactive convergence of producer services and manufacturing industry has become a mainstream trend of global economic development; the practice has proved that this is an ideal model of industrial development. This interaction features: on the one hand along with manufacturing transformation and upgrading, the demand for producer services increased, producer services attached to the manufacturing industry; on the other hand, the production of services by reducing manufacturing transaction costs of production, promote human, knowledge, technology and other means of capital deepening and enhancing the competitiveness of the industry, such as support among manufacturing development ${ }^{[1]}$.

So far, many scholars at home and abroad have done a lot of research for the relationship between producer services and manufacturing. In theory, the study of the relationship between the two can be summarized in four typical views: "Demand following theory", "supply-led theory", "interactive theory" and "the theory of fusion". "Demand following theory" ${ }^{12]}$ considered that the manufacturing industry is the premise and basis of the development of the service industry, the development of service industry is attached to the development of the manufacturing industry. "Supply-led theory" ${ }^{[3]}$ thought that service industry especially the productive service industry is the premise and foundation to improve manufacturing productivity. Chinese scholars Chen Xian and Huang Jianfeng $^{[4]}$, Gu Naihua ${ }^{[5]}$ and Liu Shuhan ${ }^{[6]}$ believed that productive service industry and manufacturing industry is the interactive relationship between the interaction, interdependence and common development. Among them, in the period of economic transformation in China, from the two aspects of division of labor and competitiveness, analyze the interactive relationship between the producer services and manufacturing sector. "Fusion theory" ${ }^{[7]}$ thought that, with the development and application of information and communication technology, the productive service industry and manufacturing industry both boundaries become increasingly blurred, presents the fusion trend. On the definition of producer services, the paper based on the "Twelfth Five-Year" Plan and the Statistical Yearbook of the classification, the producer services is defined as six industries transportation, storage and postal services, financial services, real estate, information transmission, computer services and software industry, leasing and business services, scientific research, technical services and geological prospecting, etc., which of added value indicates producer services.

\section{METHODOLOGY}

\section{A. The Method of Grey Relational Model}

In 1982, the Chinese scholar Professor Deng Julong created a series of gray system theory and model, was widely applied in the field of socio-economic practices and a variety of scientific research, and quickly spread to the world. The theory that the objective world exists in the relationship between the sizes of various types of system, not only the different systems is gray, the relationship between the different factors that same system is also gray. To this end, the theory put forward the concept of correlation analysis; through incomplete, unclear information processing system to quantify the inherent causal link can be more accurate analysis between variables. Specific steps of the method are as follows:

1) Determine the analysis sequence. First, the system must reflect the behavioral characteristics of selected data sequences that reference sequence, usually written as:

$$
X_{0}=\left\{x_{0}(\mathrm{k}) \mid k=1,2, \Lambda, \mathrm{n}\right\}
$$


For comparison with the reference number associated with the number of columns as the comparison:

$$
X_{t}=\left\{x_{t}(\mathrm{k}) \mid k=1,2, \Lambda, \quad \mathrm{n}\right\}, \mathrm{t}=1,2, \Lambda, \quad \mathrm{m}
$$

Where " $n$ " is the number of data comparing the number of columns, " $\mathrm{m}$ " is the number of the reference sequence.

2) Dimensionless variables. Since the data systems of various factors columns may vary dimension, not easy to compare or comparison is difficult to get the correct conclusion. So during gray correlation analysis, are generally required to carry out non-dimensional treatment of the data. Initialization data processing methods, mean, standardization, commonly used method is to carry out the initial processing of raw data.

3) Absolute difference sequence. Seek reference sequence and comparative sequence difference to get the absolute difference sequence $\Delta_{\mathrm{t}}(\mathrm{k})$ :

$$
\Delta_{t}(k)=\left|\mathrm{x}_{0}(k)-x_{t}(k)\right|,(\mathrm{k}=1,2, \Lambda, n ; 1 \leq t \leq m) .
$$

4) Calculate Grey correlation coefficient. Grey correlation coefficient is calculated as follows:

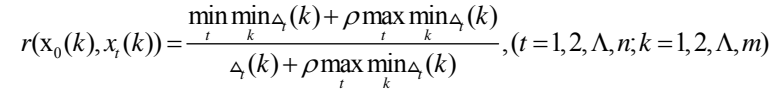

5) Seek gray correlation. Seeking gray correlation $r_{i}$ :

$$
r_{i}=\mathrm{r}\left(\mathrm{x}_{0}, x_{i}\right)=\frac{1}{n} \sum_{k=1}^{n} r\left(x_{0}(\mathrm{k}), x_{i}(\mathrm{k})\right),(\mathrm{i}=1,2, \Lambda, m)
$$

Among them, $\rho \in(0, \infty)$ called distinguish coefficient. $\rho$ is smaller, the greater the resolution, in general $\rho$ value interval $(0,1)$, usually takes $\rho=0.5$. The higher the value, the more consistent description of the sequence comparison with the reference sequence changes the situation, namely the impact of the sequence of the reference sequence is greater. The closer correlation indicates that the greater the degree of association, the comparison with the reference sequence relationship more closely, whereas the opposite.

\section{B. The Method of VAR Model}

Vector Autoregressive Model (VAR Model) ${ }^{[8]}$ can be used to predict economic time series associated with the system is a multi-equation model unstructured. This kind of model is not based on economic theory, in the form of simultaneous equations and more; with the endogenous variable lag all endogenous variables regression, which can be used to model the impulse response analysis and variance decomposition analysis, research all within dynamic relationship between endogenous variables. The model solves some endogenous variables can either be placed on the left of the equation, while equation can be placed on the right problems. P-order VAR model is expressed as follows:

$$
\begin{gathered}
Y_{t}=A_{1} Y_{t-1}+A_{2} Y_{t-2}+\cdots+B X_{t}+\varepsilon_{t}, t=1,2, \cdots, \mathrm{T} \\
\text { or }\left[\begin{array}{c}
y_{1 t} \\
y_{2 t} \\
\cdots \\
y_{k t}
\end{array}\right]=A_{1}\left[\begin{array}{c}
y_{1 t-1} \\
y_{2 t-1} \\
\cdots \\
y_{k t-1}
\end{array}\right]+\cdots+A_{p}\left[\begin{array}{c}
y_{1 t-p} \\
y_{2 t-p} \\
\cdots \\
y_{k t-p}
\end{array}\right]+B\left[\begin{array}{c}
x_{1 t} \\
x_{2 t} \\
\cdots \\
x_{k t}
\end{array}\right]+\left[\begin{array}{c}
\varepsilon_{1 t} \\
\varepsilon_{2 t} \\
\cdots \\
\varepsilon_{k t}
\end{array}\right], t=1,2, \cdots, \mathrm{T}
\end{gathered}
$$

Among them, $\mathrm{Yt}$ is the $\mathrm{K}$ dimension variable vector, $\mathrm{Xt}$ is the $\mathrm{D}$ dimension of the exogenous variable vector, $\mathrm{p}$ is the lag order, $\mathrm{T}$ is the number of samples. $\mathrm{K}^{*} \mathrm{k}$ matrix $A_{1}, A_{2}, \cdots, A_{p}$ and the $\mathrm{k}^{*} \mathrm{~d}$ matrix $\mathrm{B}$ is a matrix of coefficients to be estimated. $\varepsilon_{t}$ is a $\mathrm{K}$ dimensional perturbation vector.

\section{Index Selection and Data Collection}

This study selected two variables Guangxi manufacturing and productive service industry added value, which was expressed by $M_{t}$ and $P_{t}$. Taking into account the possible presence of problems, respectively, taking the natural logarithm of the two variables, denoted $\mathrm{LnM}_{t}, \mathrm{LnP}_{t}$.

The paper's raw data comes from 《Guangxi Statistical Yearbook》, 《Economic and social development in Guangxi statistical bulletin》, and the sample size is 17. It should be noted that, taking into account the availability of data, the Guangxi region by manufacturing value added at current prices of manufacturing value added, production of value added services by the Guangxi region of transportation, storage and postal services, the financial industry increase the total value of real estate, information transmission, computer services and software industry, leasing and business services, scientific research, technical services and geological prospecting in six industry sectors represented.

TABLE I. GUANGXI GRAY CORRELATION RESULTS

\begin{tabular}{|l|c|c|}
\hline \multicolumn{1}{|c|}{ Gray correlation matrix } & Manufacturing & Producer services \\
\hline Manufacturing & 1 & 0.825439655 \\
\hline Producer services & 0.787419547 & 1 \\
\hline $\begin{array}{l}\text { Transportation,storage and } \\
\text { postal services }\end{array}$ & 0.667049232 & 0.823146363 \\
\hline Financial Industry & 0.708583317 & 0.683558275 \\
\hline Real Estate & 0.845225579 & 0.916685856 \\
\hline $\begin{array}{l}\text { Scientific and Technical } \\
\text { Services and Geological } \\
\text { Prospecting }\end{array}$ & 0.653796741 & 0.785912779 \\
\hline $\begin{array}{l}\text { Information transmission, } \\
\text { computer services and software } \\
\text { industry }\end{array}$ & 0.689801672 & 0.795795117 \\
\hline \begin{tabular}{l} 
Leasing and Business Services \\
\hline
\end{tabular} & 0.751846663 & 0.844050639 \\
\hline
\end{tabular}




\section{EMPIRICAL ANALYSIS}

\section{A. Grey correlation results}

By gray correlation results, with the manufacturing sector as a reference sequence, correlation coefficient of manufacturing and real estate, renting and business services and the financial sector reached about 0.75 . This suggests that Guangxi manufacturing industry in addition to the affected by its own development, the traditional producer services such as leasing and business services dependence is bigger. Among them, producer services in real estate, renting and business services and financial services sectors influence and promote a greater role in Guangxi manufacturing. Producer services as a reference to the number of columns, a high degree of relevance sectors, including real estate, renting and business services, transport, storage and postal services, and the correlation coefficient was $0.916685856,0.844050639,0.823146363$. This illustrates the three department of Guangxi is relatively high; the influence of producer services is one of the leading industry selection of producer services in Guangxi. Producer services in Guangxi are still mainly traditional producer services, emerging of productive service industry development is relatively slow. On the whole, producer services and manufacturing industry in Guangxi do not form a significant interaction.

\section{B. Results based on VAR model}

In order to study the interaction Guangxi region to develop relations of producer services and manufacturing, the paper constructs VAR model in Guangxi region between producer services and manufacturing, analysis development status and long-term interaction between the two.

1) Preliminary test. Time series data analysis requires data used must be stable, if the data is non-stationary, it will lead to spurious regression problem. As can be seen from Table 2, ADF level value $\mathrm{LnM}$ and $\mathrm{LnP}$ is greater than the critical value, respectively, indicating the presence of the original sequence unit root, so $\mathrm{LnM}$ and $\mathrm{LnP}$ are non-stationary sequence. Further to its second-order difference sequence $\mathrm{D}^{2} \mathrm{LnM}$ and $\mathrm{D}^{2} \mathrm{LnP}$ inspection, its second-order differential is less than the critical value, the null hypothesis is rejected, the second-order differential sequences are stationary sequence. In summary, LnM and LnP second-order single whole sequence, denoted as I (2).

The establishment of the VAR model, Johansen co integration test, can judge the non-stationary whether there is a long-term stable equilibrium relationship between variables. As can be seen from Table 3, at the 5\% significance level, the null hypothesis "0 co integration vectors", "at most one co integrating vector", the statistic is larger than the critical value, so reject the null hypothesis. This suggests that the variable $\mathrm{LnM}$ and LnP there is a co integration relationship, namely the long-term equilibrium relationship in the manufacturing industry and producer services.
TABLE II. VARIABLES JOHANSEN COINTEGRATION

\begin{tabular}{|c|c|c|c|c|}
\hline $\begin{array}{c}\text { Null } \\
\text { hypothesis }\end{array}$ & Eigenvalues & $\begin{array}{c}\text { Trace } \\
\text { statistics }\end{array}$ & $\begin{array}{c}\mathbf{5 \%} \text { critical } \\
\text { value }\end{array}$ & $\begin{array}{c}\text { P } \\
\text { values }\end{array}$ \\
\hline None & 0.860631 & 34.2424 & 15.49471 & 0.0000 \\
\hline At most 1 & 0.26816 & 4.68291 & 3.841466 & 0.0305 \\
\hline
\end{tabular}

Granger causality test was used to analyze the causal relationships between variables. The lag was $1.5 \%$ significance level lower, $\mathrm{P}$ value is less than the critical value, the null hypothesis "LnM not LnP Granger cause" and "LnP not LnM Granger cause" have been rejected. Namely, the added value of manufacturing LnM and added value of productive LnP are granger reason; co-integration relationship between the two has causality. Increasing the value of manufacturing variations of the current period can be effectively explained previously variables, and vice versa.

TABLE III. LNM AND LNP OF GRANGER CAUSALITY TEST

\begin{tabular}{|l|c|c|c|c|}
\hline $\begin{array}{l}\text { Null } \\
\text { hypothesis }\end{array}$ & Sample & F statistic & P values & Conclusion \\
\hline $\begin{array}{l}\text { Granger } \\
\text { reason of LnP } \\
\text { not LnM }\end{array}$ & 17 & 18.9099 & 0.0008 & rejected \\
\hline $\begin{array}{l}\text { Granger of } \\
\text { reason } \\
\text { LnM not LnP }\end{array}$ & 17 & 10.8946 & 0.0057 & rejected \\
\hline
\end{tabular}

Therefore, there is a preliminary test results of long-term and stable dynamic equilibrium between the Guangxi region manufacturing and producer services and manufacturing changes in the current period of change can be effectively explained producer services, and vice versa. This also shows that show some synergy between the development of the Guangxi regional manufacturing and producer services.

In short, preliminary test shows that the manufacturing industry and producer service industry is long-term stable equilibrium relationship. It also indicates that the development of between manufacturing industry and producer services in Guangxi region shows some collaborative.

2) VAR regression estimate. By VAR model estimation results analysis, the development of the manufacturing industry in Guangxi region affected by the effects of the producer services and the own development at the same time, the lag phase 1 for manufacturing the influence coefficient of $59 \%$ and $45 \%$, respectively; But the development of productive service industry by its own development foundation effect significantly, can reach about $123 \%$, manufacturing 1 period lag coefficient of impact on producer services for -0.244152 . So there is a synergetic effect of oneway between productive service industries and manufacturing industry, namely the productive service industry out of a supporting role on the performance of manufacturing, the manufacturing industry stimulating effect on the productive service industry is not obvious.

3) Impulse response and variance decomposition. Impulse Response Function is to shock type VAR mode in a variable value for the current period and the future values of other variables brought described. Use EViews7.2 to get a pulse- 
related response function curves between manufacturing and producer services in Figure 1 and Figure 2.

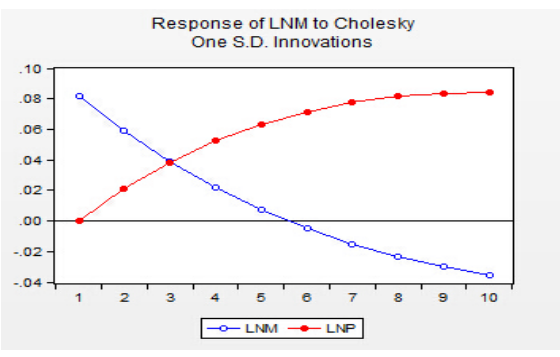

FIGURE 1. LNM RESPONSE TO SHOCKS

As can be seen from Figure 1, the manufacturing of its own with a strong one standard deviation shock response and lag a maximum of $8.2 \%$, after the impact of waning, lagged 10 low $3.5 \%$. Manufacturing of standard deviation from the producer services impulse response evident by a lagging impact gradually increased, reaching a maximum of $8.4 \%$ lagged 9 after stabilizing. This indicates that the manufacturing sector in the early Guangxi region to its stimulating effect plays a dominant role, with the development of producer services, after reaching equilibrium, the late producer services supporting role to play a leading role in manufacturing.

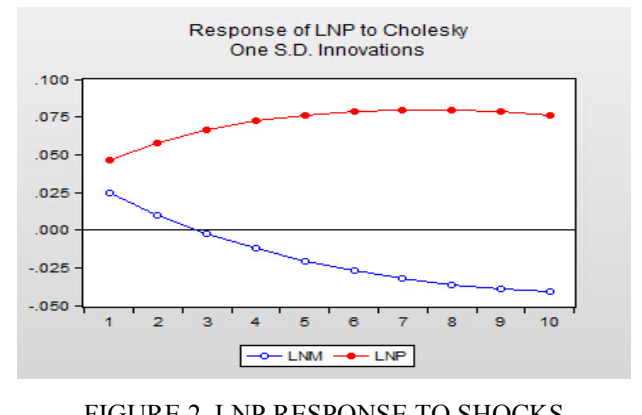

As can be seen from Figure 2, the producer services for the impact from the standard deviation of the response itself is obvious, from a minimum of $4.7 \%$ in the first, the impact gradually increased, reaching a maximum of $7.9 \%$ lagged 7 after stabilizing. The producer services to shocks from the manufacturing standard deviation of the response, by a maximum of $2.4 \%$ in the first, the impact gradually weakened, reaching $-3.8 \%$ after nine lag stabilized. This indicates that producer services Guangxi region itself has a very good role in boosting the manufacturing sector and stimulating effect on producer services gradually weakened, is not obvious.

Variance decomposition analysis method can determine the size of contribution between productive service industry and manufacturing industry. The contribution of their own role in the development of the manufacturing industry in the previous four more obvious effect of its role of producer services is growing. The role of producer services contribute to their own development is obvious, to keep down the level of $90 \%$, the effect of the manufacturing sector is relatively weak producer services.

\section{CONCLUSIONS}

From above, it can be found that there is a long-term interaction between producer services and manufacturing, but the interactive development degree is low, there is a certain partiality, namely, producer services have a certain degree of support for manufacturing, but manufacturing pull function on the producer services are not obvious. Here, In order to achieve the healthy development of producer services in Guangxi, some suggestions are put forward as follows: On one hand, to develop the producer services, improve the interactive mechanism between manufacturing and producer services. Due to the economic development and infrastructure, such as Guangxi region lagging behind the development of producer services is seriously lagging behind, the government should increase investment in producer services related to infrastructure, guide and encourage social capital investment of producer services, encourage non-state economy participate in the development of producer services in wider areas, making the industry in a variety of forms of ownership of enterprises in the open, fair, regulated market competition environment[9].On the other hand, to speed up the manufacturing of industrial upgrading, transform the mode of development. Promote the integration of information technology and manufacturing production and management, continue to strengthen and improve coordination between enterprises of the industry. At the same time, eliminate backward production capacity of traditional industries, promote restructuring, through technological innovation, improve circulation and utilization, and enhance the competitiveness of traditional industries [10].

\section{REFERENCES}

[1] Gao Chuansheng,Liu Zhibiao. Producer services and manufacturing industry agglomeration and development of the Yangtze River Delta Theoretical, Empirical and Potential Analysis[J] Shanghai Economic Research, 2005 (08): 35-42.

[2] Cohen,Zyman,"Manufacturing Maters: the Myth of the Post Industrial Economy" [J].New York, 1987.

[3] Karaomerilioglu,Carlsson. Manufacturing in decline:a matter of definition[J].Economy, Innovation, New Technology,1999,8:175-196.

[4] Chen Xian,Huang Jianfeng. Division, interactive and Integration: An Empirical Study on the relationship between the evolution of services and manufacturing [J] China Soft Science, 2004, (10): 65-71.

[5] Gu Naihua. Production Services, Endogenous Comparative Advantage and Economic Growth: A Theoretical and Empirical Analysis [J]. Business Economics and Management, 2005, (4): 34--39.

[6] Liu Shuhan, Zhang Rui, Liu Lixia. Chinese producer services and manufacturing industry analysis [J]. Nankai Economic Research, 2010,6.

[7] Zhou Zhenhua.Industry Convergence: New Power Industry Development and Economic Growth [J] China Industrial Economy, 2003, (4).

[8] He Jian.EViews econometric experiments and use [M] Beijing: China Statistics Press, 2010,4.

[9] Yu Guanghui. Development of producer services in the western region to explore - A Case Study [J] social scientists, 2013 (9).

[10] Lv Yongquan. Promote the scientific development of the manufacturing industry in Guangxi strategic thinking [J]. Economic and Social Development, 2011,8. 